\title{
A COMPARISON OF THERMOREGULATORY RESPONSES IN THE JAPANESE MACAQUE (MACACA FUSCATA) AND THE CRAB- EATING MACAQUE (MACACA IRUS) DURING COLD EXPOSURE
}

\author{
Hiromi Tokura*, Fumie Hara, Morihiko Okada, \\ Fumio MeKatA, and Wataru OHSAWA \\ Primate Research Institute, Kyoto University, Inuyama City, \\ Aichi 484, Japan
}

\begin{abstract}
Thermoregulatory responses in four male adult Japanese macaques and four male adult crab-eating macaques, weighing $6-12 \mathrm{~kg}$ and $6.2-8 \mathrm{~kg}$, respectively, were compared at ambient temperatures $\left(T_{\mathrm{a}}\right)$ ranging from $5^{\circ} \mathrm{C}$ to $25^{\circ} \mathrm{C}$. The average values \pm S.E. for some physiological measurements made at $T_{\mathrm{a}}$ of $25^{\circ} \mathrm{C}$ in the Japanese macaque and the crab-eating macaque, respectively, were as follows: resting metabolic rate; $47.6 \pm 5.0$ and $42.5 \pm 1.7 \mathrm{~W} / \mathrm{M}^{2}$; tissue conductance; $11.9 \pm 0.8$ and $8.9 \pm 0.8 \mathrm{~W} / \mathrm{M}^{2} /{ }^{\circ} \mathrm{C}$; respiratory evaporative heat loss; $4.1 \pm 0.3$ and $3.2 \pm$ $0.5 \mathrm{~W} / \mathrm{M}^{2}$; rectal temperature; $38.6 \pm 0.1$ and $37.4 \pm 0.2^{\circ} \mathrm{C}$; mean skin temperature; $34.0 \pm 0.3$ and $31.2 \pm 0.1^{\circ} \mathrm{C}$. When $T_{\mathrm{a}}$ was lowered stepwise from $25^{\circ} \mathrm{C}$ to $20,15,10$, and $5^{\circ} \mathrm{C}$ successively, and maintained constant at each temperature level for $1 \mathrm{hr}$, metabolic heat production gradually increased in both species. When $T_{\mathrm{a}}$ was lowered from $10^{\circ} \mathrm{C}$ to $5^{\circ} \mathrm{C}$, the crab-eating macaque did not show further increase in heat production and the result was a loss of thermal equilibrium with rectal temperature continuing to fall. On the other hand, the Japanese macaque maintained thermal balance even at $T_{\mathrm{a}}$ of $5^{\circ} \mathrm{C}$. Tissue conductance, which was significantly higher in the Japanese macaque than in the crab-eating macaque at $T_{\mathrm{a}}$ of 5,15 , and $25^{\circ} \mathrm{C}$, decreased in both species as $T_{\mathrm{a}}$ was lowered from $25^{\circ} \mathrm{C}$ to 15 and $5^{\circ} \mathrm{C}$. The specific differences in thermoregulatory responses are considered to be adaptational, relative to the natural habitat of the two species studied.
\end{abstract}

Received for publication September 11, 1974

* Present address: Laboratory of Physiology, Department of Clothing Science, Nara Women's University, Kitauoya-Nishimachi, Nara City, Nara 630, Japan 登倉尋実，原 文江，岡田守彦，目方文夫，大沢 済 
Because of an evolutionary resemblance to man, monkeys are being used increasingly as experimental animals in various fields of medicine and biology. However, little is known about the thermal and metabolic responses during cold or heat exposure except in a few species of primates (STITT and HARDY, 1971; NAKAYAMA et al., 1971; JOHNSON and ElizONDO, 1973). It is of interest, from the viewpoint of comparative physiology of thermoregulation, to survey the thermophysiology of various monkey species in relation to their ecology and phylogeny. The Japanese macaque is the most northerly species of monkey in the world, whose habitat ranges from Yaku Island $\left(30^{\circ} \mathrm{N}\right)$ to Shimokita Peninsula $\left(41^{\circ} \mathrm{N}\right)$ in Japan. The Japanese macaque lives in the cold snowy forests of Shimokita Peninsula and Shiga Heights in winter where the ambient temperature often falls below $-10^{\circ} \mathrm{C}$ (IzAWA and Nishida, 1963; WADA, 1964). The crab-eating macaque, on the other hand, is a tropical species inhabiting areas of Southeast Asia, including Burma, Thailand, Vietnam, Malaya, Borneo, Java, Sumatra, the Philippines and many offshore islands (NAPIER and NAPIER, 1967). The climate of these areas, in general, is hot, humid and rainy with a small annual range of temperature (DAvis, 1960).

Comparing the thermoregulatory responses of the Japanese macaque with those of crab-eating macaque, we may, therefore, obtain some knowledge about the mechanism of climatic adaptation. In the present experiments, thermal and metabolic responses between four Japanese macaques and four crab-eating macaques during cold exposure were compared.

\section{MATERIALS AND METHODS}

Four male adults of the Japanese macaque (Macaca fuscata) and crab-eating macaque (Macaca irus) weighing 6-12 $\mathrm{kg}$ and 6.2-8 $\mathrm{kg}$, respectively, were used in this study. The animals had been housed for at least 1 year in our colonies at a room temperature of $23 \pm 3^{\circ} \mathrm{C}$ throughout the year. They had been trained to sit quietly in a primate restraining chair prior to the experiments. The measurements of physiological responses were begun $2 \mathrm{hr}$ after the animals were transferred to a climatic chamber controlled at $25 \pm 1.5^{\circ} \mathrm{C}$. The ambient temperature $\left(T_{\mathrm{a}}\right)$ of the chamber was lowered stepwise from $25^{\circ} \mathrm{C}$ to $20,15,10$, and $5^{\circ} \mathrm{C}$ successively, and kept constant at each temperature level for $1 \mathrm{hr}$. Food was not given in the morning of the experimental day.

Oxygen uptake and carbon dioxide output were measured by an open-flow draw system. Oxygen and carbon dioxide contents of collected gas samples were determined by a Scholander gas analyzer. Heat production was calculated from oxygen uptake and carbon dioxide output. A plexiglass hood $(250 \mathrm{~mm}$ high, $300 \mathrm{~mm}$ wide and $300 \mathrm{~mm}$ long) placed over the animal's head was continuously ventilated at a rate of 18-22 liter/min by an air pump pulling the air from the hood and the connecting hose. Gas samples were collected into a Douglas bag for $5 \mathrm{~min}$ every $20 \mathrm{~min}$. 
Water vapor from the respiratory tract was measured by using two pairs of wet and dry bulb thermocouples. The water content of the inspired air was recorded by the first pair which was placed at the entrance to the plexiglass hood and that of the expired air by the second pair placed at the exit from the hood. As the flow rate of the air through the hood is known, the respiratory water loss can be obtained by subtracting the first value from the second.

Rectal $\left(T_{\mathrm{re}}\right)$ and skin temperatures were recorded once every minute using copper-constantan thermocouples. A rectal thermocouple, contained in a small piece of vinyl tubing, was inserted a distance of about $15 \mathrm{~cm}$ into the anus. Skin thermocouples were fixed with adhesive tape on the locally shaved body surface of the chest, leg, foot, and tail.

Using the following formula (HoRI et al., 1972), the body surface area of the Japanese macaque was estimated:

$$
S=12.3 W^{2 / 3}
$$

where $S$ is the body surface area $\left(\mathrm{cm}^{2}\right)$ and $W$ is body weight $(\mathrm{g})$. Modifying the equation determined for the Japanese macaque by HoRI et al. (1972), the mean skin temperature $\left(\bar{T}_{\mathrm{s}}\right)$ was calculated, using the following equation:

$$
\vec{T}_{\mathrm{s}}=0.448 T_{\text {chest }}+0.411 T_{\text {leg }}+0.141 T_{\text {foot }}
$$

The body surface area and proportional distribution of the regional areas in the crab-eating macaque were directly measured in each animal. Under pentobarbital sodium anesthesia at a dose of $25 \mathrm{mg} / \mathrm{kg}$, the animals were closely clipped and the body was covered with vinyl tape. The vinyl tape was then removed by regions and pressed onto a sheet of tracing paper, the weight of which per unit area was known. The tracing paper was then cut and weighed. The overall error in this procedure was estimated to be within $6.2 \%$ by tests made on a sphere of known surface area.

The rate of energy conversion per unit time, sometimes termed "power", is usually expressed in human metabolism as kcals per $\mathrm{hr}$. This can be converted to the common physical unit of joules per second or watts by the relation

$$
1 \mathrm{kcal} \text { per } \mathrm{hr}=1.16 \text { watts }
$$

Tissue conductance was calculated by the following equation:

Tissue conductance $\left(\mathrm{W} / \mathrm{M}^{2} /{ }^{\circ} \mathrm{C}\right)$

$$
=\frac{\text { rate of heat loss through skin surface }}{\text { surface area } \times\left(T_{\mathrm{re}}-\bar{T}_{\mathrm{s}}\right)}
$$

Heat loss from the skin surface in the steady state condition was estimated from the metabolic heat production and respiratory evaporative heat loss.

\section{RESULTS}

In Fig. 1, heat production, rectal temperature, mean skin temperature and 

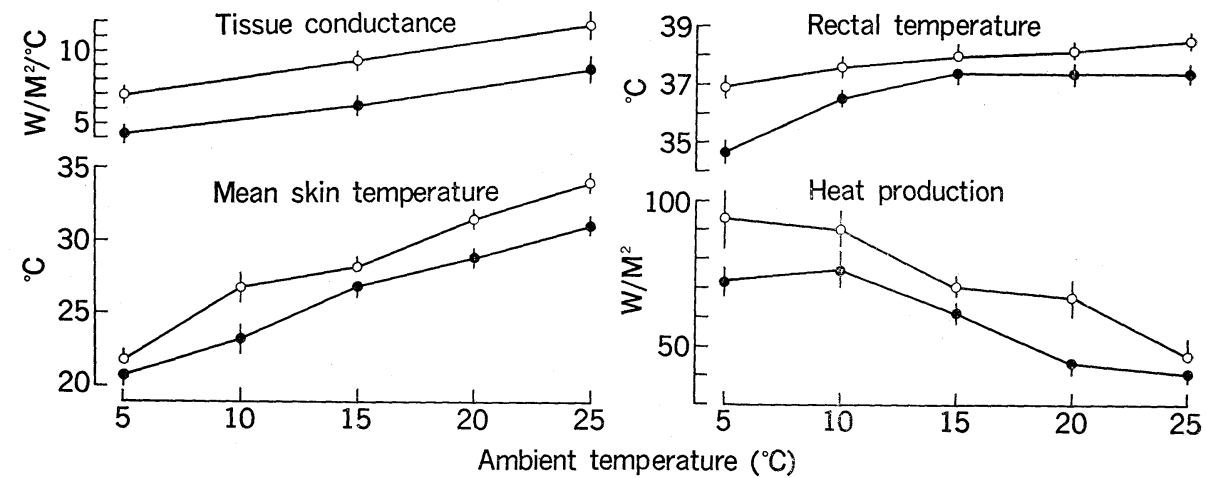

Fig 1 Hear production, rectal temperature, mean skin temperature and tissue conductance at $T_{\mathrm{a}}$ of $5-25^{\circ} \mathrm{C}$ in the Japanese macaque and the crab-eating macaque. Japanese macaque; $\bigcirc$ : crab-eating macaque. Vertical segments denote standard error of means.

tissue conductance are compared at $T_{\mathrm{a}}$ of $5-25^{\circ} \mathrm{C}$ between four Japanese macaques and four crab-eating macaques. At $T_{\mathrm{a}}$ of $25^{\circ} \mathrm{C}$ the average value of heat production was $47.6 \pm 2.0 \mathrm{~W} / \mathrm{M}^{2}$ (mean \pm standard error) in the Japanese macaque and $42.5 \pm 1.7 \mathrm{~W} / \mathrm{M}^{2}$ in the crab-eating macaque. As $T_{\mathrm{a}}$ was lowered, heat production gradually increased in both species, showing consistently higher values in the Japanese macaque than those in the crab-eating macaque. The maximum metabolic rate was attained at $5^{\circ} \mathrm{C}$ in the Japanese macaque and at $10^{\circ} \mathrm{C}$ in the crabeating macaque. At $25^{\circ} \mathrm{C}$ the average value of $T_{r e}$ was $38.6 \pm 0.1^{\circ} \mathrm{C}$ in the Japanese macaque and $37.4 \pm 0.2^{\circ} \mathrm{C}$ in the crab-eating macaque. $T_{\mathrm{re}}$ was significantly higher in the Japanese macaque than in the crab-eating macaque at each $T_{\mathrm{a}}$ ( $p<$ 0.01 for $T_{\mathrm{a}}=5,10,15$ and $25^{\circ} \mathrm{C} ; p<0.05$ for $T_{\mathrm{a}}=20^{\circ} \mathrm{C}$ ). When $T_{\mathrm{a}}$ was lowered from $25^{\circ} \mathrm{C}$ to $20,15,10$, and $5^{\circ} \mathrm{C}, \bar{T}_{\mathrm{s}}$ gradually decreased in both species. $\bar{T}_{\mathrm{s}}$ was consistently higher in the Japanese macaque than in the crab-eating macaque at each $T_{\mathrm{a}}$. At $25^{\circ} \mathrm{C}$ the average value of tissue conductance was $11.9 \pm 0.8 \mathrm{~W} / \mathrm{M}^{2} /{ }^{\circ} \mathrm{C}$ in the Japanese macaque and $8.9 \pm 0.8 \mathrm{~W} / \mathrm{M}^{2} /{ }^{\circ} \mathrm{C}$ in the crab-eating macaque. Tissue conductance decreased in both species as $T_{\mathrm{a}}$ was lowered from $25^{\circ} \mathrm{C}$ to 15 and $5^{\circ} \mathrm{C}$. Tissue conductance was significantly higher in the Japanese macaque than in the crab-eating macaque at $T_{\mathrm{a}}$ of 5,15 , and $25^{\circ} \mathrm{C}\left(p<0.01\right.$ for $T_{\mathrm{a}}=5$ and $25^{\circ} \mathrm{C} ; p<0.02$ for $T_{\mathrm{a}}=15^{\circ} \mathrm{C}$ ). During $1 \mathrm{hr}$ 's exposure to $5^{\circ} \mathrm{C}$ the Japanese macaque could maintain thermal equilibrium by elevating the metabolic heat production and decreasing tissue conductance while the crab-eating macaque could not, with $T_{\mathrm{re}}$ continuing to fall. Respiratory evaporative heat loss was $4.1 \pm 0.3 \mathrm{~W} / \mathrm{M}^{2}$ in the Japanese macaque and $3.2 \pm 0.5 \mathrm{~W} / \mathrm{M}^{2}$ in the crab-eating macaque at $25^{\circ} \mathrm{C}$, and $2.8 \pm 0.3 \mathrm{~W} / \mathrm{M}^{2}$ and $4.3 \pm 0.5 \mathrm{~W} / \mathrm{M}^{2}$, respectively, at $5^{\circ} \mathrm{C}$. Thus, no significant difference was detected in respiratory evaporative heat loss either between $25^{\circ} \mathrm{C}$ and $5^{\circ} \mathrm{C}$ in each species or between the two species at each $T_{\mathrm{a}}$. 


\section{DISCUSSION}

During cold exposure to $5^{\circ} \mathrm{C}$ the Japanese macaque was able to maintain thermal equilibrium by elevating heat production and decreasing tissue conductance while the crab-eating macaque was unable to do, showing a continuing fall in rectal temperature. This is thought to be related to the facts that the Japanese macaque is geographically distributed in areas where the air temperature falls below $-10^{\circ} \mathrm{C}$ in winter, while the crab-eating macaque inhabits chiefly the tropical rain forests where the air temperature is mild throughout the year. A marked decline in body temperature below $T_{\mathrm{a}}$ of $10^{\circ} \mathrm{C}$ has been reported for the tree shrew (Bradley and Hudson, 1974) and the pigmy marmoset (Morrison and MiddleTON, 1967) which also live in tropical rain forests. In the rhesus macaque, acclimated at $T_{\mathrm{a}}$ of $25^{\circ} \mathrm{C}$ for more than 1 year, which is geographically distributed in snowy areas during winter months, the rectal temperature was well maintained at $T_{\mathrm{a}}$ of $5^{\circ} \mathrm{C}$ (Tokura et al., 1975) and for at least $3 \mathrm{hr}$ even at $T_{\mathrm{a}}$ of $-6^{\circ} \mathrm{C}$ (CHAFFEE and Allen, 1973). These findings suggest that the thermal characteristics of various monkey species may be reflected on their thermoregulatory ability.

As seen in Fig. 1, heat production which did not become reduced over $T_{\mathrm{a}}$ of $25^{\circ} \mathrm{C}$ (Tokura et al., 1975), began to increase in both species when $T_{\text {a }}$ was lowered from $25^{\circ} \mathrm{C}$ to $20^{\circ} \mathrm{C}$. Therefore, the critical ambient temperature for the increase of metabolic activity seemed to lie between 20 and $25^{\circ} \mathrm{C}$.

Respiratory evaporative heat loss did not change significantly in both species studied when $T_{\mathrm{a}}$ was lowered from $25^{\circ} \mathrm{C}$ to $5^{\circ} \mathrm{C}$. Similar phenomenon has been reported in the Japanese macaque (NAKAYAMA et al., 1971) and the squirrel monkey (STITT and HARDY, 1971).

The decrease in tissue conductance with falling $T_{\mathrm{a}}$ from $25^{\circ} \mathrm{C}$ to $5^{\circ} \mathrm{C}$ indicates peripheral vasoconstriction caused by cold exposure. Our data, however, are inconsistent with the findings in the Japanese macaque (NAKAYAMA et al., 1971) that the reduction in tissue conductance in the cold environment is very small in comparison to the value in the neutral zone. Also in the squirrel monkey exposed to cold, STITT and HARDY (1971) found only a slight reduction in tissue conductance. The significant higher tissue conductance in the Japanese macaque compared with that in the crab-eating macaque at $T_{\mathrm{a}}$ of 5,15 , and $25^{\circ} \mathrm{C}$, might be ascribed to the higher metabolic heat production observed in the former species at each $T_{\mathrm{a}}$.

The specific differences in thermoregulatory responses to cold between the Japanese macaque and the crab-eating macaque are considered to be of adaptational significance in relation to the natural habitats of the species studied.

The authors wish to express their thanks to Dr. Dorothy J. Cunningham for her critical reading of this manuscript. 


\section{REFERENCES}

Bradley, S. R. and Hudson, J. W. (1974) Temperature regulation in the tree shrew Tupaia glis. Comp. Biochem. Physiol., 48A: 55-60.

Chaffee, R. R. L. and Allen, J. R. (1973) Effects of ambient temperature on the resting metabolic rate of cold- and heat-acclimated Macaca mulatta. Comp. Biochem. Physiol., 44A: 1215-1225.

Davis, F. K., Jr. (1960) Climatic conditions in the natural environment of monkeys. Ann. N.Y. Acad. Sci., 85: 747-751.

Hori, T., Tokura, H. and TADAKI, E. (1972) Surface area in the Japanese monkey, Macaca fuscata. J. Appl. Physiol., 32: 409-411.

IzAWA, K. and NishidA, T. (1963) Monkeys living in the northern limits of their distribution. Primates, 4: 67-88.

Johnson, G. S. and Elizondo, R. S. (1973) Thermoregulation in Macaca mulatta: a thermal balance study. Physiologist, 16: 353 .

Morrison, P. and Middleton, E. H. (1967) Body temperature and metabolism in the pigmy marmoset. Folia Primat., 6: 70-82.

Nakayama, T., Hori, T., Nagasaka, T., Tokura, H., and TAdaki, E. (1971) Thermal and metabolic responses in the Japanese monkey at temperatures of 5-38 ${ }^{\circ}$. J. Appl Physiol., 31: 332-337.

NAPIER, J. R. and NAPIER, P. H. (1967) A Handbook of Living Primates. Academic Press, London, pp. 207-219.

StITT, J. T. and HARDY, J. D. (1971) Thermoregulation in the squirrel monkey (Saimiri sciureus)。 J. Appl. Physiol., 31: 48-54.

Tokura, H., Hara, F., Okada, M., Mekata, F. and Ohsawa, W. (1975) Thermoregulatory responses at various ambient temperatures in some primates. Proc. 5th Cong. Int. Primat. Soc. Karger, Basel, in press.

WADA, K (1964) Some observations on the life of monkeys in a snowy district of Japan. Physiol. Ecol., 12: 151-174 (in Japanese with English summary). 